\title{
COMPARATIVE ANALYSIS OF LIVING CONDITIONS IN SETTLEMENTS OF NORTHERN VOJVODINA
}

\section{UPOREDNA ANALIZA USLOVA ŽIVOTA U NASELJIMA SEVERNE VOJVODINE}

\author{
Karolina Kajari, docent \\ Budapesti Corvinus Egyetem \\ Address: $\quad$ Tolnai Lajos u. 361084 Budapest \\ Phone: $\quad+3614826177$ \\ E-mail: $\quad$ karolina.kajarik@uni-corvinus.hu
}

Šomođi Šandor, profesor emeritus

Address: $\quad$ Lifka Sandor u. 2924000 Subotica

Phone: $\quad+38124542265$

E-mail: $\quad$ bio-nat-yu@tippnet.rs 


\title{
COMPARATIVE ANALYSIS OF LIVING CONDITIONS IN SETTLEMENTS OF NORTHERN VOJVODINA
}

\section{UPOREDNA ANALIZA USLOVA ŽIVOTA U NASELJIMA SEVERNE VOJVODINE}

Keywords: living, working, urban, rural, analysis, Northern Vojvodina

\begin{abstract}
The Regional Scientific Society seated in Subotica realized a research trough a questionnaires method about the living and working conditions of inhabitants of Northern Vojvodina settlements.

As the main hypothesis of this publication is formulated; a difference in the living conditions, chances and viewpoints of rural and urban population.

The task of the publication is to test trough a comparative analysis and regression analysis of living conditions of rural and urban population the main hypothesis. The education level, the occupation, ambitions, financial conditions and some opinions of rural and urban population has been used as dependent, and the domicile as independent variable.

The cross-tables in which the answers of the questionnaires ere arranged show the frequencies, the structures and present an opportunity to realize the comparative analysis.

The existence and the intensity of relations is tested and measured trough Csuprov association's index.
\end{abstract}

Ključne reči: životni, radni, urbani, ruralni, analiza, Severna Vojvodina

\section{Rezime}

Regionalno Naučno Društvo iz Subotice je realizovao istraživanje o životnim i radnim uslovima stanovništva Severne Vojvodine metodom upitnika.

Formulisana je glavna hipoteza istraživanja po kojem postoje razlike izmedju životnih i radnih uslova ruralnog i urbanog stanovništva.

Glavni je zadatak ove publikacije da prikaže rezultate ispitivanja životnih i radnih uslova urbanog i ruralnog stanovništva uporednom i regresionom analizom. Nivo obrazovanosti, zanimanje, ambicije, finansijski uslovi i stavovi urbanog i ruralnog stanovništva su korišćene kao zavisno promenljive a mesto stanovanja kao nezavisno promenljiva.

Tabelarno prikazani podaci o odgovorima pokazuju frekvencije i strukture koje su omogućile realizaciju uporednih analiza.

Postojanje i intenzitet relacija je testiran i meren asocijativnim indeksom Čuprova. 


\section{Uvod}

Regionalno Naučno Društvo sa sedištem u Subotici je krajem 2009. godine (pod rukovodstvom vodećeg istraživača Šomodji Šandora, Prof. Emeritusa) metodom upitnika realizovalo šire istraživanje vezano za kvalitet života i zadovoljstva - nezadovoljstva stanovništva severnog regiona Vojvodine, koji obuhvata Suboticu, Bačku Topolu, Mali Idjoš, Kanjižu, Sentu, Adu, Bečej i Čoku. Iz tog istraživanja je izdvojen problem razlika između nekih pokazatelja načina života seoskog i gradskog stanovništva.

Postojanje razlike u životnim uslovima, šansama i stavovima seoskog i gradskog stanovništva formulisana je kao nulta hipoteza - polazna pretpostavka prikaza. (1)

Zadatak saopštenja je da kroz uporedni prikaz uslova života i rada seoskog i gradskog stanovništva i uporedne analize dobijenih podataka testira valjanost polazne pretpostavke. U analizu su uključene sledeće zavisne promenljive: školska sprema, zanimanje, ambicije, finansijski i stambeni uslovi i pojedini stavovi i mišljenja seoskog i gradskog stanovništva, dok mesto stanovanja predstavlja nezavisnu promenljivu.

\section{Metoda}

Upitnikom je obuhvaćeno 786 stanovnika regiona, što predstavlja 0,24\% ukupnog stanovništva (3). Odgovori su obrađeni statističkim programskim paketom SPSS. Pored analize učestalosti dobijenih odgovora izvršene su i cross-tab analize dobijenih odgovora.

Sem analize učestalosti podaci su podvrgnuti i analizi zavisnosti pomoću tzv. Čuprovljevog koeficijenta međuzavisnosti ${ }^{1}$, sa ciljem da se otkriju razlike i sličnosti u životnim i radnim uslovima, zdravstvenom stanju i kvalitetu života gradskog i seoskog stanovništva anketom obuhvaćenog regiona.

Stavovi i mišljenja ispitanika analizirani su metodom rangiranja i upoređenjem dobijenih rangova Spearman-ovim koeficijentom korelacije ranga. ${ }^{2}$

\footnotetext{
${ }^{1}$ Koeficijent meri intenzitet asocijacije promenljivih, grupisanih prema određenim kriterijima. Ako su grupisane pojave nezavisne vrednost koeficijenta je 0 , dok u slučaju funkcionalne veze vrednost iznosi 1 . U svim ostalim slučajevima vrednost kofeicijenta se nalazi u intervalu 0-1. (2)

${ }^{2}$ Spirmanov koeficijent korelacija ranga meri sličnosti-razlike među pojedinim rangovima. Ako su rangovi isti vrednost koeficijenta je 0 , ako su potpuno različiti 1 , a ako su suprotni -1. (2)
} 


\section{Karakteristike uzorka}

Od upitnikom obuhvaćenih 786 ispitanika, 56,2\% su bile žene i 42,5\% muškarci. 1,3\% ispitanika je pitanje polne pripadnosti ostavilo bez odgovora.

$76,46 \%$ ispitanika se isjasnilo kao Mađari, 17,17\% kao Srbi i 4,83\% kao ostalo. 1,53\% ispitanika se nije izjasnilo po pitanju nacionalne pripadnosti.

Starosna struktura ispitanika je prikazana u tabeli 1.

Tabela 1 Starosna struktura ispitanika

\begin{tabular}{|l|r|r|}
\hline \multicolumn{1}{|c|}{ Godine } & Ǔ̌estalost & \multicolumn{1}{c|}{$\%$} \\
\hline $18-30$ & 228 & 29,04 \\
\hline $31-40$ & 191 & 24,33 \\
\hline $41-50$ & 161 & 20,51 \\
\hline $51-60$ & 147 & 18,73 \\
\hline $60+$ & 58 & 7,39 \\
\hline Ukupno & $\mathbf{7 8 5}$ & $\mathbf{1 0 0}$ \\
\hline
\end{tabular}

Više od polovine ispitanika (52\%) živi u bračnoj i 9,4\% u vanbračnoj zajednici. Razvedeno živi 7,5\% ispitanika, udovci i udovice čine 4,8\% uzorka, dok 2,4\% ispitanika živi neudato ili neoženjeno.

\section{Rezultati analiza}

\section{1. Šanse na tržištu rada}

Školska sprema ispitanika prikazana je u tabeli 2.

Tabela 2. Školska sprema ispitanika

\begin{tabular}{|l|r|r|}
\hline \multirow{2}{*}{\multicolumn{1}{|c|}{ Školska sprema }} & \multicolumn{2}{c|}{ Struktura u \% } \\
\cline { 2 - 3 } & \multicolumn{1}{c|}{ Selo } & \multicolumn{1}{c|}{ Grad } \\
\hline Osnovna škola & 18,60 & 12,69 \\
\hline Škola učenika u privredi & 18,29 & 14,70 \\
\hline Srednja stručna škola & 33,23 & 37,86 \\
\hline Gimnazija & 7,32 & 11,14 \\
\hline Viša škola & 12,5 & 14,48 \\
\hline Fakultet & 8,54 & 7,79 \\
\hline $\begin{array}{l}\text { Specijalizacija, postgradualno } \\
\text { osposobljavanje }\end{array}$ & 0,61 & 0,89 \\
\hline PhD, doktorat & 0,91 & 0,45 \\
\hline Ukupno & $\mathbf{1 0 0 , 0 0}$ & $\mathbf{1 0 0 , 0 0}$ \\
\hline
\end{tabular}


Analiza dobijenih odgovora pokazuje da seosko stanovništvo blago zaostaje za gradskim stanovništvom u pogledu obrazovanosti. Skoro svaki šesti seoski stanovnik ima samo završenu osnovnu školu, njih 58,84\% ima završeni neki oblik srednjeg obrazovanja i samo $22,56 \%$ seoskog stanovništva ima završenu višu školu, fakultet ili neki oblik specijalizacije.

U isto vreme, među gradskim stanovništvom samo svaki osmi ima završenu osnovnu školu. Učešće onih koji imaju srednje obrazovanje je 63,70\%, dok višu i visoku spremu i neki oblik specijalizacije ima 23,61\% gradskog stanovnštva.

Slika postaje još turobnija ako analiziramo namere gradskog i seoskog stanovništva vezane za doškolovanje, usavršavanje. (Slika 1)

Slika 1

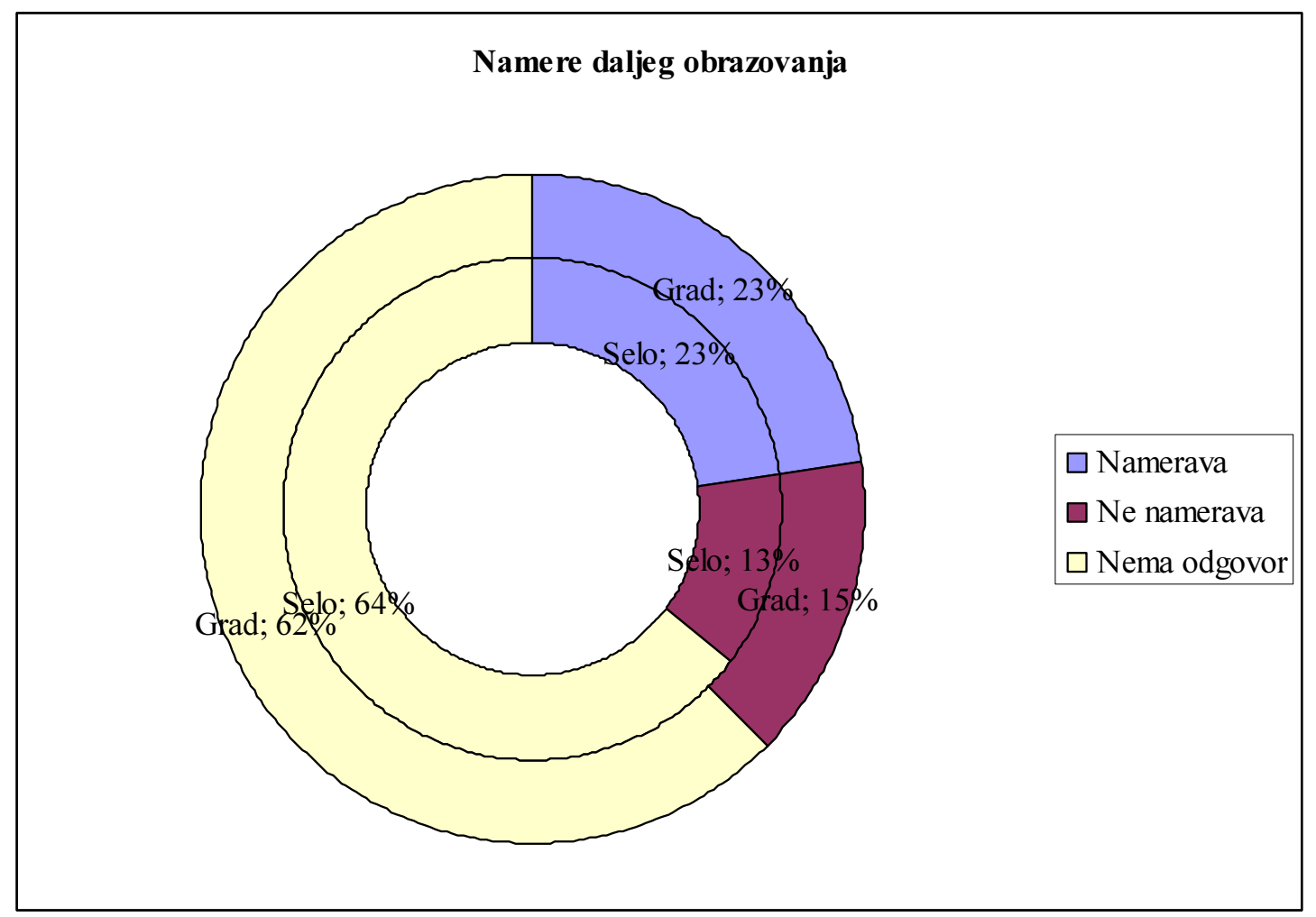

Stavovi po pitanju doškolovanja, promene zanimanja ili usavršavanja su u obe analizirane grupe bili veoma ujednačeni. Kako u gradskoj, tako i u seoskoj zajednici samo 23\% ispitanika se izjasnilo pozitivno po tom pitanju. Veliki deo ispitanika na pitanje da li u budućnosti namerava da se doškoluje, promeni zanimanje, ili usavrši postojeće nije ni odgovorilo, što se može smatrati svojevrsnim negativnim odgovorom. 
Mišljenja smo, da ovaj odbojni stav prema učenju treba da nas zabrine. Osnovna škola i srednje obrazovanje već i danas predstavlja problem kako pri zapošljavanju tako i pri vršenju redovnih poslova i zadataka. Brze promene tehnologije koje nameće modernizacija privrede zahteva stalno usavršavanje i učenje, da bi kompetencije zaposlenih mogle da slede zahteve radnog mesta. Doživotno učenje (Lifelong Learning) nije samo slogan, već bi trebao biti osnovni princip ponašanja zaposlenih ali i onih koji čekaju zaposlenje. U protivnom će beznadežno izgubiti korak na tržištu rada.

Struktura zanimanja ispitanika prikazana je u tabeli 3.

Tabela 3 Zanimanje ispitanika

\begin{tabular}{|l|r|r|}
\hline \multicolumn{1}{|c|}{ Zanimanje } & \multicolumn{2}{c|}{ Struktura u \% } \\
\cline { 2 - 3 } & \multicolumn{1}{c|}{ Selo } & \multicolumn{1}{c|}{ Grad } \\
\hline Učenik/Student & 3,69 & 5,57 \\
\hline Diplomirani stručnjak koji čeka prvo zaposlenje ili planira da & 2,77 & 2,00 \\
započne svoje preduzeništvo & & \\
\hline Preduzetnik & 7,08 & 7,35 \\
\hline Administrativni radnik & 6,77 & 13,36 \\
\hline Radnik u privatnoj ili državnoj firmi & 45,23 & 44,99 \\
\hline Radnik na prinudnom odmoru & 0,31 & 0 \\
\hline Samostalni poljoprivredni proizvođač & 7,38 & 2,23 \\
\hline Radnik u poljoprivredi & 0,62 & 0,45 \\
\hline Povremeni radnik & 1,85 & 2,89 \\
\hline Domaćica & 6,15 & 3,12 \\
\hline Penzioner & 8,61 & 11,36 \\
\hline Nezaposleni/porodiljsko & 9,54 & 6,68 \\
\hline Ukupno & $\mathbf{1 0 0 , 0 0}$ & $\mathbf{1 0 0 , 0 0}$ \\
\hline
\end{tabular}

Stanovite razlike u zanimanju gradskog i seoskog stanovništva mogu se zapaziti kod učenika/studenata. Među gradskim stanovništvom je učešće učenika/studenata veće za $50,95 \%$. Pojava se može posmatrati kao posledica činjenice da je većina mladih prinuđena da za vreme školovanja živi u gradu kao podstanar ili u srednjoškolskom/studentskom domu, te se pri ispitivanju izjašnjava kao stanovnik grada. 
Lokacija opštinskih, republičkih administracija u gradovima nužno nameće veće učešće administrativnih radnika u gradskim sredinama. Skoro dvostruko veće učešče administrativnih radnika među gradskim stanovništvom posledica je činjenice da u seoskim zajednicama lokalna samouprava obavlja samo manje poslove i zadatke, dok republička skoro nikakve, što značajno umanjuje mogućnosti seoskog stanovništva za upošljavanje u ovim oblastima.

Slična je situacija i kada su u pitanju zaposleni u poljoprivredi i samostalni poljoprivredni proizvođači. Dok udeo zaposlenih u poljoprivredni i samostalnih poljoprivrednih proizvođača u seoskim sredinama iznsi $8 \%$, u gradkim sredinama je to svega $2,68 \%$. U stvari od troje ljudi koji se bave poljoprivredom dvoje živi na selu i samo jedan u gradu.

Veće učešće administrativnih radnika među gradskim stanovništvom, nasuprot većem učešču poljoprivrednika među seoskim se može smatrati normalnom pojavom usled društvene podele rada na nivou selo-grad.

Približno isto učešće ispitanika koji sa diplomom čekaju ili traže prvo zaposlenje, kao i onih koji rade u državnim ili privatnim preduzećima u obe analizirane grupe ukazuje na činjenicu da se šanse seoskog i gradskog stanovništva bitno ne razlikuju pri zapošljavanju.

\section{2. Životni uslovi}

Stambene uslove ispitanika prikazuje tabela 4. Posmatrajući kvalitet stambenog objekta u kojem ispitanici žive možemo konstatovati da je među gradskim stanovništvom trostruko veći udeo onih koji žive u, prema sopstvenoj proceni, luksuznoj kući ili stanu. Kod ostalih ponuđenih klasifikacija nema bitnih razlika. Udeo seoskog i gradskog stanovništva u konfornim, prosečnim, nekonfornim stanovima pa čak i u prinudnom smeštaju je skoro izjednačen.

Što se vlasništva tiče, među seoskim stanovništvom $86,79 \%$ stambenog fonda je $u$ sopstvenom vlasništvu, 6,14\% iznajmljeno i za 7,07\% stambenih objekata ne raspolažemo informacijama u vlasništvu, samo o stepenu konfora. U gradskoj sredini udeo stambenih objekata u sopstvenoj svojini je 81,23\%, iznajmljenih 11,04\% i ne raspolažemo informacijama o vlasništvu kod 7,73\% stambenih objekata.

Blaga razlika koja se u vlasništvu stambenog objekta pojavljuje u korist seoskog stanovništva rezultat je činjenice da je seosko stanovništvo manje-više i poslom vezano za selo u kojem obavlja poljoprivrednu proizvodnju, te je manje pokretljivo od gradskog 
stanovništva. U njihovom slučaju sasvim je racionalno ponašanje da se trajno nastani u selu, u sopstvenoj kući i obrađuje zemlju u okolini. Kada je reč o gradskom stanovništvu, njihova strukovna mobilnost je izraženija, jer kao administrativni radnik, lekar itd. može bilo gde da se zaposli, te mu nije $\mathrm{u}$ interesu da sticanjem vlasničkog prava na stambeni prostor smanji svoju pokretljivost, mobilnost na tržištu rada.

Tabela 4 Stambeni uslovi ispitanika

\begin{tabular}{|c|c|c|}
\hline \multirow{2}{*}{$\begin{array}{l}\text { Kvalitet i vlasništvo stambenog } \\
\text { objekta }\end{array}$} & \multicolumn{2}{|c|}{ Struktura u \% } \\
\hline & Selo & Grad \\
\hline Luksuzna kuća/stan & 0,31 & 0,22 \\
\hline - sostvena & 0,31 & 1,76 \\
\hline - iznajmljena & 0 & 0,45 \\
\hline Komforna kuća/stan & 2,15 & 1,32 \\
\hline - sopstvena & 31,57 & 30,46 \\
\hline - iznajmljena & 1,84 & 2,65 \\
\hline Prosečna kuća/stan & 3,68 & 5,74 \\
\hline - sopstvena & 52,15 & 46,80 \\
\hline - iznajmljena & 3,68 & 6,18 \\
\hline Nekomforna kuća/stan & 0,31 & 0 \\
\hline - sopstvena & 2,76 & 1,76 \\
\hline - iznajmljena & 0 & 1,54 \\
\hline Prinudni smeštaj & 0,62 & 0,45 \\
\hline - sopstven & 0 & 0,45 \\
\hline - iznajmljen & 0,62 & 0,22 \\
\hline Ukupno & 100,00 & 100,00 \\
\hline
\end{tabular}

Nužno je međutim napomenuti, da je ovako visoko učešče sopstvenog vlasništva nad stambenim prostorom veoma visoko u poređenju sa razvijenim zapadnim zemljama, i nužno predstavlja jedan od uzroka strukturne nezaposlenosti - nemobilnosti u svim onim zemljama gde imamo slično visok vlasnički udeo u stambenom prostoru.

Obzirom na osetljivost problema mesečnih primanja, ispitanici su se samostalno izjašnjavali o visini svojih primanja, svrstajući sebe u jednu od ponuđenih kategorija. Podaci i 
informacije nisu bile naknadno proveravane. Mesečna primanja ispitanika, po sopstvenim izjavama prikazana su na slici 2.

Slika 2.

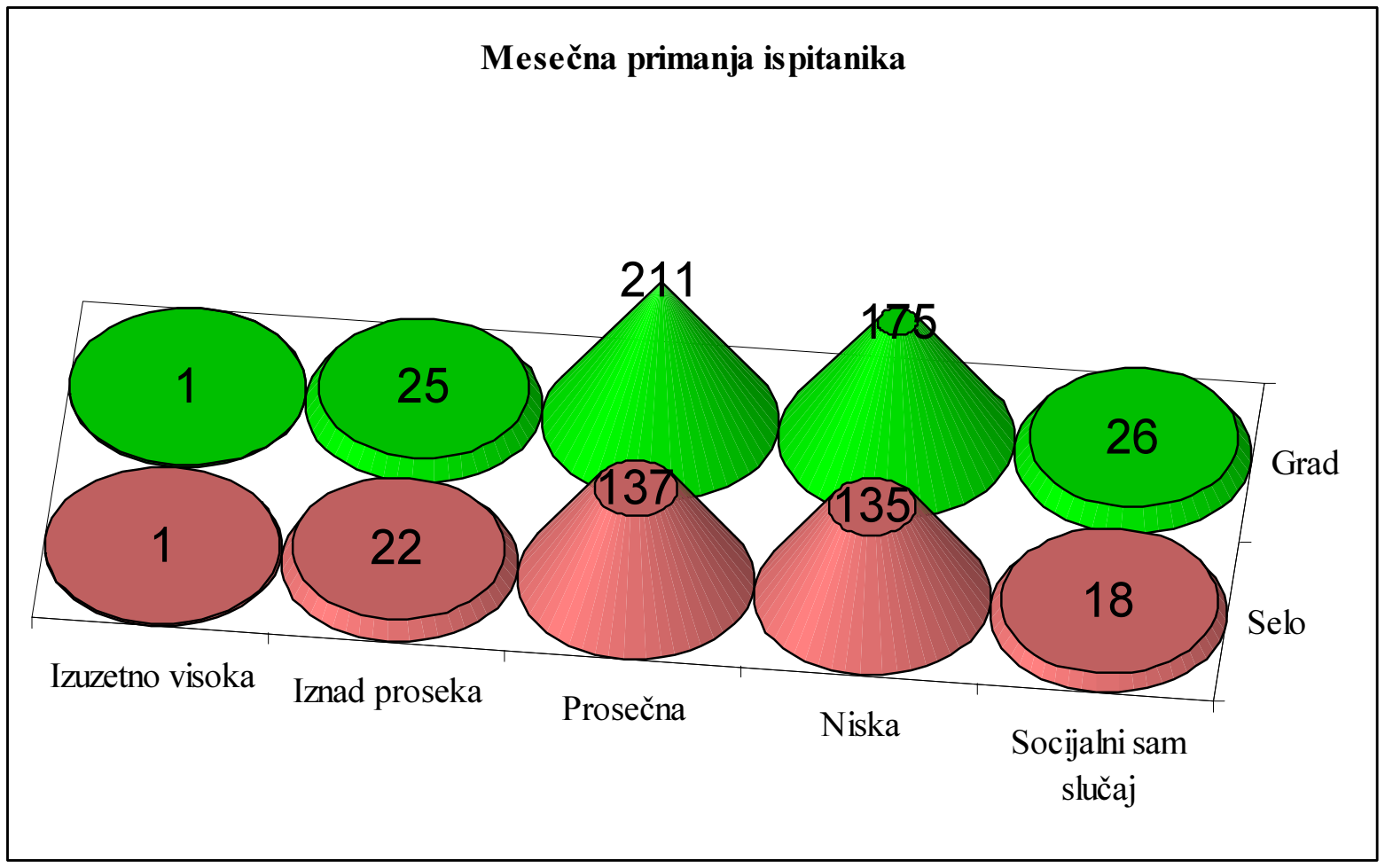

Analiza apsolutnog broja ispitanika ukazuje na blagu prednost gradskog stanovništva po pitanju visine mesečnih prihoda. Analiza relativnog udela pojedinih kategorija primanja, međutim pomalo menja situaciju. Seoski ispitanici sa izuzetno visokim primanjem čine $0,32 \%$ ukupne seoske populacije. Istovremeno, samo $22 \%$ gradskog stanovništva ocenjuje svoje primanje izuzetno visokim. Isto tako 22 ispitanika seoske populacije sa primanjima iznad proseka čine 7,03\% ukupne seoske populacije, dok 25 ispitanika gradske populacije sa primenjima iznad proseka čini 5,71\% gradske populacije. U skladu sa time, u seoskoj populaciji može se zapaziti nešto veće učešće ispitanika sa primanjima iznad proseka (ukupno 7,35\%) u odnosu na grasku populaciju (ulupno 5,93\%).

Kada je reč o prosečnim primanjima, udeo gradskog stanovništva je veće $(48,12 \%)$ u odnosu na seosko $(43,77)$, dok kod niskih primanja seosko stanovništvo opet ima veći udeo $(43,13 \%)$ u odnosu na 39,95\% udela gradskog stanovništva. Ova pojava je dobro poznata i slično terminu „agrarna makaza“, nazivamo „makazom primanja za seoski rad“, što označava da seljak i seoski stanovnik za isti ili vrlo često i teži rad prima manje naknade od 
gradskih stanovnika. Ovoj pojavi vrlo često se dodaje i stav, po kojem je „seljak uvek siromašniji od onog koga snabdeva hranom“.

Udeo socijalnih slučajeva je u obe kategorije skoro isto. 5,75\% kod seoske i 5,94\% kod gradske populacije.

\subsection{Zdravlje, porodični život i zadovoljstvo}

Pošto životni i radni uslovi mogu biti od presudnog uticaja na zdravlje ljudi analizirali smo i zdravstveno stanje ispitanika (Tabela 5).

Tabela 5 Zdravstveno stanje ispitanika

\begin{tabular}{|l|r|r|}
\hline \multirow{2}{*}{ Ocena } & \multicolumn{2}{|c|}{ Učešće u \% } \\
\cline { 2 - 3 } & Selo & Grad \\
\hline Ne zna -0 & 3,36 & 2,45 \\
\hline Jako loše -1 & 1,53 & 1011 \\
\hline Loše -2 & 3,06 & 4,67 \\
\hline Osetljivo -3 & 11,62 & 12,67 \\
\hline Dobro -4 & 52,29 & 51,56 \\
\hline Odlično -5 & 28,13 & $27,56 /$ \\
\hline \multirow{2}{*}{ Ukupno } & $\mathbf{1 0 0 , 0 0}$ & $\mathbf{1 0 0 , 0 0}$ \\
\hline
\end{tabular}

I gradsko i seosko stanovništvo je svoje zdravstveno stanje ocenilo pretežno kao dobro i odlično. Dodelimo li mogućim odgovorima numeričke vrednosti, kako je to prikazano u prvoj koloni tabele 5 prosečna vrednost zdravstvenog stanja seoskog stanovništva je 4,06, a gradskog 4,02, pri čemu broj onih koji ne znaju oceniti zvoje zdravstveno stanje nije uzet $\mathrm{u}$ obzir.

Ispitanike smo zamolili da ocene svoj porodični život. Ako analiziramo ceo uzorak, možemo zaključiti da $1,16 \%$ ispitanika uopšte ne želi osnovati porodicu, 5,94\% nema porodicu, dok se 7,33\% ispitanika se stalno bori sa problemima. Svoj porodični život smatra prosečnim 54,63\% ispitanika i uravnoteženim 30,71\%.

Analiza strukture dobijenih odgovora ukazuje na jednu vrlo interesantnu pojavu. Među gradskim stanovništvom dvaput je veći udeo ispitanika koji ne žele osnovati porodicu 
(66,7\%) nego u selu (33,33\%). Slično ovoj pojavi među gradskim stanovništvom veći je udeo onih koji žale, što nemaju porodicu.

Među onima koji se stalno bore sa problemima znatno je veći udeo seoskog stanovništva, dok prosečnim i uravnoteženim svoj život smatraju većinom stanovnici gradova. (Slika 3)

Odgovori na pitanje vezano za zadovoljstvo ispitanika svojim dosadašnjim životnim putem (tabela 6) pokazuju nešto drugačiju sliku od zadovoljstva porodičnom situacijom. Svojim životnim putem je nezadovoljno 1,31\% ispitanika, od kojih 69,32\% živi u gradu a jedva 3\% na selu. Pitanja upitnika nisu bila usmerena na razloge nezadovoljstva, te stoga ne raspolažemo tačnim uzrocima ovog stanja. Preosaje nam da pretpostavimo da dinamičniji gradski život, veći broj mogućih zanimanja, poslova i šansi gradskom stanovništvu nameće stalnu mogućnost i prinudu upoređivanja postignutog i pretpostavljenog mogućeg životnog puta, i to kontinuelno upoređivanje stvara veće šanse za nezadovoljstvo.

Slika 3

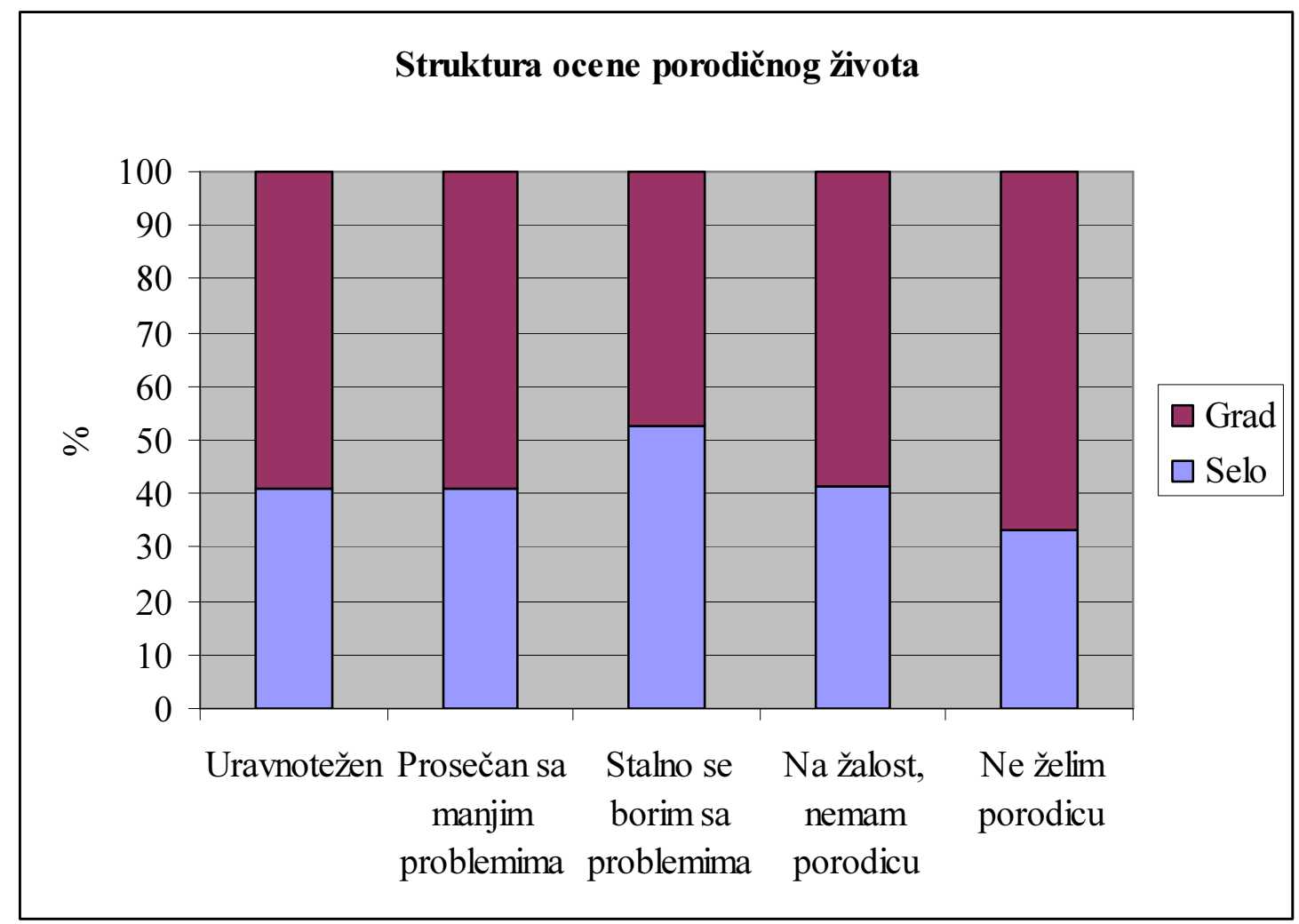


Tabela 6 Zadovoljstvo ispitanika svojim životnim putem

\begin{tabular}{|l|r|r|}
\hline \multirow{2}{*}{ Ocena } & \multicolumn{2}{|c|}{ Učešće u \% } \\
\cline { 2 - 3 } & \multicolumn{1}{|c|}{ Selo } & \multicolumn{1}{c|}{ Grad } \\
\hline Zadovoljan sam & 28,13 & 29,71 \\
\hline Delimično sam zadovoljan & 63,61 & 56,76 \\
\hline Nezadovoljan sam & 8,26 & 13,53 \\
\hline Ukupno & 100,00 & 100,00 \\
\hline
\end{tabular}

\subsection{Neka mišljenja i stavovi u vezi faktora zadovoljstva - nezadovoljstva i opšti neanalitički stav o kvalitetu života}

Zadovoljstvo odnosno nezadovoljstvo kao element kvaliteta uslova života gradskog i seoskog stanovništva uporedili smo kroz stepen njihovog zadovoljstva sa:

- Javnom bezbednošću

- Komunalnim uslugama

- Policijom

- Kvalitetom života

Moguće ocene su se kretale od 1 do 5, sa sledećim sadržajem:

- Uopšte nisam zadovoljan 1.

- Nisam zadovoljan 2

- Osrednje sam zadovoljan 3

- Zadovoljan sam 4

- Jakos sam zadovoljan 5

Uporedni prikaz proseka ocena prikazuje slika 4. 
Slika 4.

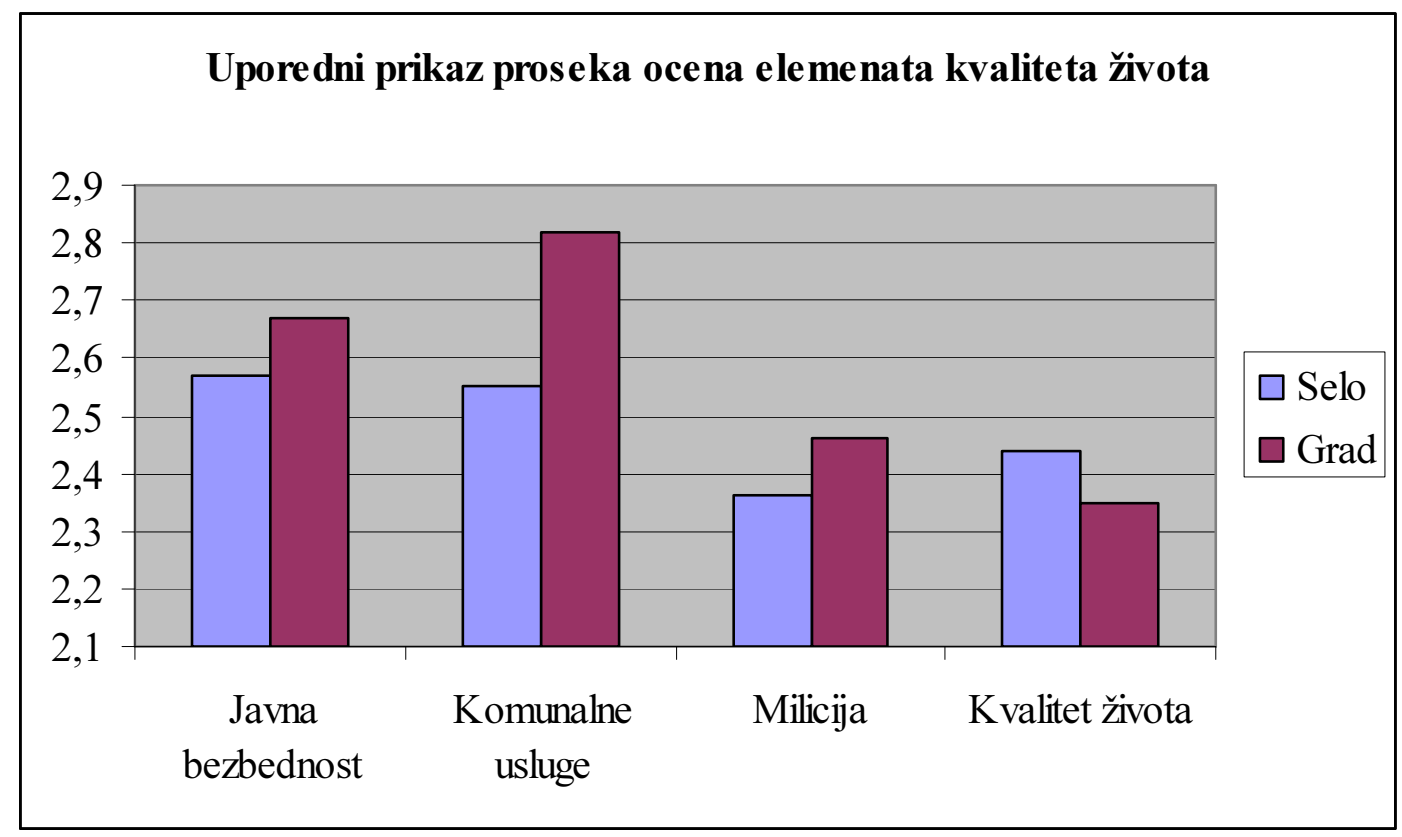

$\mathrm{Na}$ osnovu dobijenih odgovora može se zaključiti da ukupno posmatrano ispitanici nisu preterano zadovoljni navedenim kategorijama. Sve prosečne ocene nalaze se u intervalu 2,32-2,82. Seoski stanovnici od svih ponuđenih elemenata najvišu ocenu dodeljuju javnoj bezbednosti, zatim sledi kvalitet komunalnih usluga, kvalitet života i na kraju rad policije. Ova poslednja ocena je donekle protivurečna srazmerno viskoj ocena javne bezbednosti, i ukazuje na činjenicu da se u manjim životnim zajednicama, gde se ljudi poznaju osećaju sigurnije samo po sebi, a manje zahvaljujući institucionalnim čuvarima reda. Rad policije je, prema našem mišljenju je ocenjen toliko nisko zbog loše organizacije poslova i zadataka koje treba da obavljaju ovih organi prema stanovništvu.

Nasuprot seoskom stanovništvu gradsko stanovništvo komunalne usluge ocenjuje kao najkvalitetnije, mada je prosek ocena i ovde samo 2,82. Javna bezbednost je na drugom mestu, zadovoljstvo policijom na trećem, i kvalitet života na poslednjem.

Kod svih kategorija zapaža se da su stanovnici grada zadovoljniji. Izuzetak predstavlja kvalitet života, gde je seosko stanovništvo zadovoljnije.

Na pitanje koje od nabrojenih zadataka države smatra hitnim, ispitanici su mogli označiti i više zadataka. $\mathrm{Na}$ osnovu ukupnih odgovora formirani su rangovi hitnih zadataka posebno za seosko i posebno za gradsko stanovništvo, kao u rang ukupnih odgovora. (Tabela 7): 
Tabela 7 Rangovi hitnih zadataka

\begin{tabular}{|l|c|c|c|}
\hline \multirow{2}{*}{ Zadatak } & \multicolumn{2}{c|}{ Rang zadatka } & Svi \\
\cline { 2 - 4 } & Selo & Grad & ispitanici \\
\hline Ekonomski oporavak & 1 & 1 & 1 \\
\hline Izručenje ratnih zločinaca & 4 & 4 & 4 \\
\hline Socijalni mir & 3 & 2 & 2 \\
\hline Članstvo EU & 2 & 3 & 2 \\
\hline Reforma vojske i milicije & 6 & 6 & 6 \\
\hline Povratak stručnjaka iz inostranstva & 5 & 5 & 5 \\
\hline
\end{tabular}

Dobijeni rangovi pokazuju da i gradsko i seosko stanovništvo najhitnijim zadatkom smatra ekonomski oporavak. Svojevrsno iznenađenje predstavlja visoki rang učlanjenja u EU među seoskim stanovništvom, za razliku od gradskog, koji ovaj zadatak rangira na treće mesto.

Ovakav stav seoskog stanovništva prema članstvu u EU objašnjavamo željom poljoprivrenih proizvođača za većim tržištem za svoje proizvode, većim premijama i regresima, dok se manje razmišlja o negativnim posledicama otvorenog tržišta poljoprivrednih i prehrambenih proizvoda.

Socijalni mir je prema gradskom stanovništvu drugi najbitniji zadatak koji treba rešiti. Ovo mišljenje je u potpunosti u skladu sa činjenicom da je život u gradu skuplji, komplikovaniji od života na selu, da je socijalno raslojavanje gradskog stanovništva veće, i da ekonomske neprilike gradovi uvek osećaju u većoj meri nego stanovnici sela. Stoga je sasvim razumljivo zašto stanovnici grada socijalne tenzije smatraju većim problemom od članstva EU.

Izručenje ratnih zločinaca obe analizirane grupe rangiraju na četvrto mesto. Reformu vojske i policije kao i povratak stručnjaka iz inostranstva seoski stanovnici smatraju jednako važnim, rangirajući ih na peto mesto. Mišljenje stanovnika grada se malo razlikuje, jer je za njih od ova dva zadatka povratak stručnjaka iz inostranstva hitniji.

Na pitanje „Šta vas najviše zabrinjava“ ispitanici su takođe mogli dati više odgovora. Na osnovu broja dobijenih odgovora izradili smo rang razloga za zabrinutost posebno za seosko i gradsko stanovništvo i za ukupan broj ispitanika (Tabela 8) 


\section{Tabela 8 Rang razloga za zabrinutost ispitanika}

\begin{tabular}{|c|c|c|c|}
\hline \multirow[t]{2}{*}{ Razlog za zabrinutost } & \multicolumn{2}{|c|}{ Rang razloga } & \multirow{2}{*}{$\begin{array}{c}\text { Svi } \\
\text { ispitanici }\end{array}$} \\
\hline & Selo & Grad & \\
\hline Nedostatak novca & 1 & 1 & 1 \\
\hline Nezaposlenost & 2 & 2 & 2 \\
\hline Stambeni uslovi & 6 & 6 & 6 \\
\hline Školovanje dece & 5 & 4 & 5 \\
\hline Zdravstveni problemi & 3 & 3 & 3 \\
\hline Osnivanje porodice & 4 & 5 & 4 \\
\hline
\end{tabular}

Nedostatak novca za sve ispitanike, bez obzira na mesto stanovanja predstavlja najbitniji razlog za zabrinutost. Nedostatak novca slede nezaposlenost i zdravstveni problemi rangovani podjednako na drugo i treće mesto. Na četvrtom mestu kao razlog za zabrinutost seoski stanovnici navode osnivanje porodice, što je, poznavajući procese starenja seoskog stanovništva sasvim razumljivo. Mlade stanovnike sela brine nedostatak mladog ženskog stanovništva, koje se mahom školuje i nakon školovanja napušta selo, dok starije - roditelje - brine porodični život dece. Kod gradskog stanovništva je na četvrtom mestu kao razlog za zabrinutost školovanje dece. Obzirom da se i kod seoskog i kod gradskog stanovništva stambeni problemi mogu smatrati rešenim, ovaj razlog za zabrinutost je kod obe grupe ispitanika na poslednjem mestu.

\section{Zaključci}

- Seosko stanovništvo jednoznačno zasostaje po obrazovanosti u odnosu na gradsko.

- Stav ispitanih prema usavršavanju, doškolovanju i promeni zanimanja podjednako je negativan i u gradovima i na selu.

- Neprihvatanje „doživotnog učenja“ treba da nas zabrinjava, zbog gubitka prostora na tržištu rada širokog sloja ispitanih.

- Učešće takozvanog administrativnog osoblja je skoro dvostruko veće u gradovima nego u seoskim naseljima.

- Šanse seoskog stanovništva za zapošljavanje su neuporedivo slabije u odnosu na gradsko stanovništvo.

- Uslovi stanovanja na selu daleko zaostaju za gradovima. 
- Najveći deo stambenih objekata je u vlasništvu građana kako u gradovima tako i u selima, što sprečava veću mobilnost radne snage.

- Mobilnost gradskog stanovništva je nešto izrazitija od seoskog.

- Prihodi gradskog stanovništva nadmašuju prihode seoskog stanovništva.

- Obe grupe ispitanih ocenili svoje zdravstveno stanje kao zadovoljavajuće.

- U gradovima je veće učešće onih koji ne žele osnovati porodicu, ali istovremeno je veće učešće i onih koji žale što nemaju porodicu.

- Gradski stanovnici smatraju svoj život uravnoteženijim od seoskih stanovnika.

- Stanovništvo je podjednako nezadovoljno bezbednošću, komunalnim uslugama, policijom i kvalitetom života, sa tim da je gradsko stanovništvo nešto zadovoljnije komunalnim uslugama, što je posledica bolje komunalne infrastrukture.

- Rangiranje hitnih zadataka i rangiranje uzroka za zabrinutost se podudaraju kod gradskog i seoskog stanovika.

- Čuprovljev koeficijent associjacije kod svih zavisnih promenljivih pokazuje mali stepen uticaja mesta stanovanja na zavisnu promenljivu. Najveću vrednost koeficijenta od 0,1093 smo izračunali kod zaposlenja, što znači da mesto stanovanja najviše utiče na mesto zaposlenja, dok na sve ostale nezavisne promenljive ima neznatan uticaj. ${ }^{3}$

- Spirmanov koeficijent korelacije ranga potvrđuje visoku sličnost u mišljenju gradskog i seoskog stanovništva, bilo da se radi o hitnim zadacima bilo o razlozima za zabrinutost. Mera slaganja rangova hitnih zadataka je 0,91, a razloga za zabrinutost 0,94 , što nužno nameće zaključak da i gradsko i seosko stanovništvo muče isti problemi,

\section{Literatura}

1. Erhart, Szilárd (2008): Gumitalpas szent tehenek. Népszabadság, 2008. december 30.

2. Köves Pál - Párniczky Gábor (1975): Általános statisztika. 2. javított kiadás. Közgazgasági és Jogi Könyvkiadó, Budapest

\footnotetext{
${ }^{3}$ Moramo, međutim naglasiti, da niska vrednost koeficijenta ukazuje na činjenicu da ni ovaj uticaj nije od velikog značaja, jer se smatra da sve vrednosti koeficijenta ispod 0,3 ukazuju na slabu asocijaciju između zavisne i nezavisne promenljive.
} 
DETUROPE - THE CENTRAL EUROPEAN JOURNAL OF REGIONAL DEVELOPMENT AND TOURISM Vol.3 Issue 12011

3. Rebublički Zavod za Statistiku: Popis stanovništva 2002. godine http://webrzs.stat.gov.rs/ 


\section{Extended abstract}

Regional Science Association seated in Subotica performed a survey with questionnaires at the end of 2009 dealing with the quality of life and satisfaction dissatisfaction of the population living in the northern region of Vojvodina, including municipalities of Subotica, Bačka Topola, Mali Iđoš, Kanjiža, Senta, Ada, Čoka and Bečej. From the results of that survey we have pointed out the differences between some indicators of the way of life in urban and rural areas.

The existence of differences in living conditions, opportunities and attitudes of rural and urban population is defined as the initial hypothesis - our starting assumption.

The analysis included the following as dependent variables: educational level, occupation, ambitions, financial and housing conditions, and individual attitudes and opinions of urban and rural population, while the place of living is the independent variable.

The survey included 786 residents of the region, which represents $0.24 \%$ of the total population. Responses have been processed by the SPSS statistical software package. In addition to analysing the frequency of responses obtained, cross-tab analysis of the responses has also been performed. Besides the analysis of frequency data were subjected to analysis based on so-called Tschuprow's association coefficient, in order to discover differences and similarities of living and working conditions, health status and quality of life of urban and rural population covered by the survey region. The views and opinions of the respondents were analysed using the method of ranking, and comparing the ranks obtained by Spearman's rank correlation coefficient.

Analysis of responses shows that rural population slightly lags behind urban population in terms of education.

Opinions about additional training, changing job or professional development were very homogeneous in both analysed groups. Only $23 \%$ of the respondents, both in urban and rural communities, expressed positively in this regard.

Negative attitude towards learning should concern us. Having only a primary school or secondary education represent a problem in employment and in carrying out regular tasks.

Sites of municipal and state administrations in towns impose higher share of administrative workers in urban areas.

The situation is similar in terms of the share of people working in agriculture and of independent farmers. While their share in rural areas is $8 \%$, in urban areas it is only $2.68 \%$. 
Looking at the quality of housing in which respondents live, we can state the share of those who live in, as they say, a luxury home or apartment is three times more among the urban population than in villages. In case other classifications offered, there were no substantial differences. The share of rural and urban population in comfortable, average, and uncomfortable homes and even in compulsory billets is almost equal.

Concerning ownership, among the rural population $86.79 \%$ of the housing stock is in their own property, while in urban areas the share of housing in their own property is $81.23 \%$.

It is necessary to note, however, that such a high proportion of ownership of residential properties is very high compared with developed countries, and necessarily is one of the causes of structural unemployment - immobility in all those countries, which have similar high stake private-owned homes.

In terms of the amount of monthly income the analysis of the absolute number of respondents indicates a slight advantage of the urban population. In the group of people with low-income, rural population still has a larger share. This phenomenon is known as "parity" or "the gap in income for rural labour", which means that farmers and rural residents receive less compensation for the same or often even more difficult work than urban residents. This phenomenon is often complemented with the saying: "The peasant is always poorer than the one who is supplied with the food."

Both the urban and rural population have rated their health as good or excellent.

Answers to questions relating to respondents' satisfaction with their past life show a slightly different picture compared to satisfaction with family situation. In towns there are more respondents dissatisfied with their life's path. We assume that dynamic city life, greater number of possible occupations, jobs and opportunities impose urban population a constant chance and obligation for comparing their current life with their expectations, and this continuous comparison makes them dissatisfied more probably.

We have compared satisfaction - dissatisfaction as elements of the quality of life of urban and rural population evaluating the degree of their satisfaction with: public safety, utilities, police and the quality of life.

Possible ratings ranged from 1 to 5 , with the following content: 1 - I am not satisfied at all, 2 - I am not satisfied, 3 - I am moderately satisfied, 4 - I am satisfied, 5 - I am very satisfied.

Based on replies it can be concluded that in general, respondents are not very satisfied with the above categories. All average ratings are in the range from 2.32 to 2.82 . 
Rural residents awarded the highest mark of all elements offered to public safety, followed by the quality of municipal services, quality of life and at the end of the work of police.

The urban population, in contrast to rural one, estimates utilities as the most satisfactory, although the average grade even here is only 2.82. Public safety is at the second, the work of police is at the third place, and the quality of life is ranked the worst.

In all categories inhabitants of urban areas seen more satisfied. The only exception is the quality of life, where rural people are happier.

When asked which of the enumerated duties of the state is considered an emergency, respondents could mark more answers. Based on the total responses, we have formed ranks of urgent tasks, separately for rural and urban population, as well as the rank of all responses.

The ratings show that both urban and rural population consider economic recovery for the most urgent task. Surprisingly, joining the EU is ranked first among the rural population, in contrast to towns, where this task is ranked third. We think that this attitude of the rural population towards EU membership could be explained with the farmers' desire for greater markets for their products, higher premiums and subsidies, while they think less of the negative consequences of open markets for agricultural and food products.

Social peace is the second most important task to be solved according to population in towns.

Both analysed groups ranked the extradition of war criminals in the fourth place.

When asked, "What are you most concerned about?" the respondents were also able to give multiple answers.

Lack of money is the most important cause of concern for all respondents, regardless of their place of living. Lack of money is followed by unemployment and health problems being ranked both in the second and third place. 


\section{Hungarian Extended abstract}

\section{Kivonat}

A szabadkai székhelyü Regionális Tudományos Társaság 2009. végén kérdőíves felmérést végzett Vajdaság északi részének lakossága körében életkörülményeinek, megelégedettségének - elégedetlenségének felmérésére. A megkérdezéssel Szabadka, Bácstopolya, Kishegyes, Magyarkanizsa, Zenta, Ada, Becse és Csóka lakosait kereste meg. A részletes és átfogó felmérésből a falusi és városi életmód egyes mutatóinak különbözőségét választottuk az értekezés témájának.

A kutatás alaphipotézise, hogy a falusi és városi lakosság életkörülményeiben, esélyeiben és véleményében vannak jellemző különbözőségek.

Az elemzés függő változóit az: iskolai végzettség, foglalkozás, ambíciók, pénzügyi helyzet, lakhatási körülmények, egészségi állapot, életminőség, és a városi és falusi lakosság egyes álláspontjai, véleményei, független jellemzőjét pedig a lakóhely jellege alkotta.

A feldolgozott kérdőívek száma 786 volt, ami a régió összlakosságának 0,24\%-a. A kapott válaszokat az SPSS statisztikai program segítségével dolgoztuk fel és elemeztük. A gyakorisági sorok elemzése mellett az adatokat kereszttáblázatokba rendeztük, összetételvizsgálatot és a Csoprov-féle együttható segítségével összefüggésvizsgálatot végeztünk, annak érdekében, hogy feltárjuk a vizsgált régió falusi és városi lakosságának élet-, és munkakörülményei, egészségi állapota és életminősége közötti különbségeket. A megkérdezetek álláspontjai és véleményei alapján rangsorokat állítottunk fel, és a kapott rangsorokat a Spearmna-féle rangkorrelációs együtthatóval hasonlítottuk össze.

A kapott válaszok elemzése azt mutatja, hogy a falusi lakosság iskolai végzettsége kedvezőtlenebb a városi lakossághoz viszonyatva.

A továbbképzés, a szakmai váltás kérdéseiben mindkét vizsgált csoport egyformán gondolkodik. Mind a falusi, mind a városi lakoságnak csak 23\%-a nyilatkozik pozitívan ebben a kérdésben.

A tanulás elutasítása nagyon aggasztó. Az általános iskolai, de a középiskolai végzettség már ma is nehézséget jelent a munkavállalánál, de sokszor a folyamatos munkavégzésnél is.

A községi és köztársasági szakszolgálatok városban történő koncentrációja törvényszerűen jár azzal, hogy a városi lakosság között sokkal nagyobb az adminisztratív munakkörökben foglalkoztatottak részaránya. 
Hasonló a helyzet a mezőgazdaságban foglalkoztatottak és a mezőgazdasági magántermelők esetében is. Falusi környezetben a mezőgazdaságba foglalkoztatottak és a mezőgazdasági magántermeők aránya $8 \%$, a városi lakosok között viszont 2,68\%.

A lakások minőségét vizsgálva megállapítható, hogy a városi környezetben háromszor nagyobb azoknak az aránya akik, saját bevallásuk szerint, luxus körülményeket biztosító házban vagy lakásban élnek. A többi felkínált lakáskategória esetében nincs jelenős különbség a falusi és városi lakosság között. A falusi és városi lakosság aránya a konfortos, átlagos, és konfort nélküli lakásokban szinte azonos.

Ami a lakóingatlanok tulajdonjogát illeti a falun a lakóingatlanok 86,79\%-a van saját tulajdonban, míg a városi lakosság körében ez az arány 81,23\%.

Hangsúlyozni kell azonban, hogy a saját tulajdon aránya, a fejlett nyugati országokban mért arányhoz képest nagyon magas, és törvényszerüen vezet a strukturális munkanélküliség kialakulásához - röghözkötöttséghez azokban az orszgokban, ahol a saját tulajdonban lévő lakóingatlanok aránya ilyen magas.

A havi jövedelmek vizsgálata a magas jövedelmeknél a városi lakosság előnyét mutatja. Az alacsonyabb keresetűek között viszont nagyobb a falusi lakosség részaránya.Ez jól ismert jelnség, és az „,agrárolló“ kifejezés mintájára „a falusi munkabér-olló“ kifejezéssel írják le, és azt takarja, hogy a földmüvesnek, illetve a falusi lakosnak ugyanazért, vagy sokszor még nehezebb munkáért kevesebbet fizetnek, mint a városlakóknak. A jelenséghez sokszor az a vélemény is társul, hogy „A földmüves mindig szegényebb, mint az akit etet.“

Mind a városi, mind a falusi lakosság egészségi állapotát többnyire jónak és kitünőnek értékelte.

Az eddigi életúttal való elégedettség és a családi élettel való elégedettségre adott válaszok némi eltérést mutatnak. Az életútjukkal elégedetlenek között többnyire városi lakosok vannak. Felételezzük, hogy a dinamukusabb városi élet, a munkaalkalmak, munkafeladatok nagyobb választéka a városi lakosságnak nagyobb összehasonlítási lehetőséget és egyben folyamatos kényszert is jelent az elértek és az elérhetők közötti összehasonlításra, ami növeli az elégedetlenség esélyeit.

A falusi és városi életkörülményekkel való elégedettséget a lakosság: közbiztonsággal, kommunális szolgáltatásokkal, rendőrséggel és életminőségével kapcsolatos véleményén keresztül próbáltuk lemérni.

A lehetséges értékek 1-től 5-ig terjedtek a következő tartalommal: Egyáltalán nem vagyok elégedett - 1, Elégedetlen vagyok - 2, közepesen vagyok elégedett - 3, elégedett vagyok -4 , nagyon elégedett vagyok -5 . 
A kapott válaszokból megállapítható, hogy a válaszadók összességében nem túlzottan elégedettek a fenti kategóriállak. Az értékelések átlaga 2,32 és 2,82 között változik. A falusi lakosság lagnagyobb mértékben a közbiztonsággal elégedett, utána a kommunális szolgáltatásokkal, az életminőséggel és végül a rnedőrséggel. Ezzel ellentétben a városi lakosság a kommunális szolgáltatásokkal a legelégedettebb, még úgy is, hogy az értékelés átlaga 2,82. A második helyen a közbiztonság, a harmadikon a rendőrség és a negyediken az életminőség van.

Minden kategóriánál megfigyelhető a városi lakosság nagyobb elégedettsége. Kivételt képez az életinőséggel való elégedettség, amely a falusi lakosság esetében nagyobb.

Az állam sürgős feladataira vonatkozó kérdésnél a válaszadók több feladatot is megjelölhettek. A kapott válaszok összesítése után kialakult a sürgős feladatok rangsora, külön a városi és falusi lakosság esetében, valamint az összegezett, általános rangsor.

A rangsorolás azt mutatja, hogy mind a falusi, mind a városi lakosság az ország gazdasági helyeztének javítását tartja a legsürgősebb feladatnak. Meglepetést okozott az EU-hoz való csatlakozás magas rangsorszáma a falusi lakosság körében, ahol ez a tennivaló a második helyre került. A városi lakosság ezt a feladatot csak a harmadik helyre rangsorolta. Véleményünk szerint nem tévedünk sokat, ha a falusi lakosság EU csatlakozás iránti igényét azzal magyarázzuk, hogy a mezőgazdasági termelők ebben nagyobb piaci lehetőségeket látnak termékeik számára, nagyobb támogatást remélnek, és kevésbé veszik számításba a mezőgazdasági termékek és élelmiszerek szabad piaci versenyének negatív hatásait.

A városi lakosság a sürgős feladatok közül a szociális békét rangsorolta a második helyre. A háborús bünösök kiadását mindkét kategória a negyedik helyre sorolta.

A „Mi jelenti az ön számára a legnagyobb gondot?“ szintén több lehetséges választ fogadtunk el. A pénzhiány minden válaszadó számára gondot jelentett, tekintet nélkül lakóhelyének jellegére. Ezt követi a munkanélküliség, és az egészségügyi problémák, amelyek mindkét kategóriánál a rangsor második és harmadik helyére kerültek. 